Article

\title{
Biologically Synthesized Gold Nanoparticles Ameliorate Cold and Heat Stress-Induced Oxidative Stress in Escherichia coli
}

\author{
Xi-Feng Zhang ${ }^{1}$, Wei Shen ${ }^{2}$ and Sangiliyandi Gurunathan ${ }^{3, *}$ \\ 1 College of Biological and Pharmaceutical Engineering, Wuhan Polytechnic University, Wuhan 430023, \\ China; zhangxf9465@163.com \\ 2 Key Laboratory of Animal Reproduction and Germplasm Enhancement in Universities of Shandong, \\ College of Animal Science and Technology, Qingdao Agricultural University, Qingdao 266109, China; \\ shenwei427@163.com \\ 3 Department of Stem Cell and Regenerative Biology, Konkuk University, Seoul 143-701, Korea \\ * Correspondence: sangiliyandi@konkuk.ac.kr; Tel.: +82-2-450-0457
}

Academic Editor: Derek J. McPhee

Received: 28 April 2016; Accepted: 30 May 2016; Published: 4 June 2016

\begin{abstract}
Due to their unique physical, chemical, and optical properties, gold nanoparticles (AuNPs) have recently attracted much interest in the field of nanomedicine, especially in the areas of cancer diagnosis and photothermal therapy. Because of the enormous potential of these nanoparticles, various physical, chemical, and biological methods have been adopted for their synthesis. Synthetic antioxidants are dangerous to human health. Thus, the search for effective, nontoxic natural compounds with effective antioxidative properties is essential. Although AuNPs have been studied for use in various biological applications, exploration of AuNPs as antioxidants capable of inhibiting oxidative stress induced by heat and cold stress is still warranted. Therefore, one goal of our study was to produce biocompatible AuNPs using biological methods that are simple, nontoxic, biocompatible, and environmentally friendly. Next, we aimed to assess the antioxidative effect of AuNPs against oxidative stress induced by cold and heat in Escherichia coli, which is a suitable model for stress responses involving AuNPs. The response of aerobically grown E. coli cells to cold and heat stress was found to be similar to the oxidative stress response. Upon exposure to cold and heat stress, the viability and metabolic activity of E. coli was significantly reduced compared to the control. In addition, levels of reactive oxygen species (ROS) and malondialdehyde (MDA) and leakage of proteins and sugars were significantly elevated, and the levels of lactate dehydrogenase activity (LDH) and adenosine triphosphate (ATP) significantly lowered compared to in the control. Concomitantly, AuNPs ameliorated cold and heat-induced oxidative stress responses by increasing the expression of antioxidants, including glutathione (GSH), glutathione S-transferase (GST), super oxide dismutase (SOD), and catalase (CAT). These consistent physiology and biochemical data suggest that AuNPs can ameliorate cold and heat stress-induced oxidative damage in E. coli. Our results indicate that AuNPs may be effective antioxidants. However, further studies are needed to confirm the role of AuNPs as antioxidative agents, as well as their mechanism of action.
\end{abstract}

Keywords: Escherichia coli; gold nanoparticles; heat stress; cold stress; oxidative stress; antioxidants

\section{Introduction}

Gold nanoparticles (AuNPs) are being used in biomedical applications such as cancer therapy (as drug carriers), cellular imaging, molecular diagnosis, and targeted therapy, and as contrast agents, photothermal agents, and radiosensitizers. Their usefulness is due to their stability and unique optical, magnetic, electronic, oxidation resistance, and structural properties, as well as to their structure, 
composite, and shape [1,2]. AuNPs, among other metallic nanoparticles, have attracted much interest in cancer research, due to their facile synthesis and surface modification, strongly enhanced and tunable optical properties, and excellent biocompatibility. Another major advantage of using AuNPs is that their preparation is simple, with high quality and high yield, and their size can be controlled $[2,3]$.

Several methods have been established for synthesis of AuNPs, including physical, chemical, and biological methods. Chemical methods are the most widely and traditionally used, and rely on various reducing agents such as hydrazine and sodium borohydride [1,3]. Although the physical and chemical methods appear to be simple, they have numerous disadvantages, such as the necessity for high temperatures and pressures and toxic chemicals; most importantly, they can cause the particles to become unstable or aggregate upon interaction with biological media or biomolecules [3-5]. Furthermore, they require a long centrifugation process to produce multi-shaped or controlled-size particles. Recently, biological methods have shown much promise in producing nanomaterials using an environmentally friendly approach and biological material as a reducer, along with stabilizing agents to produce shape- and size-controlled particles for mass production with high yield, solubility, reproducibility, and biocompatibility [1,3]. Several microorganisms and plant extracts have been used for synthesis of AuNPs, including Lactobacillus strains [6], Bacillus licheniformis [7], Brevibacterium casei [8], Aspergillus fumigatus [9], edible mushroom extract [10], and medicinal mushroom extract [3]. Although several reports have demonstrated synthesis of AuNPs using a variety of biological materials, exploration of novel biological materials is warranted, because every living entity has unique surface functionalization properties that can provide significant biocompatibility to targeting agents.

Stress response in bacteria is an essential and indispensable protection against various external stimuli. It leads to changes in the physiological state of the bacterial culture itself [11]. Biological structures in bacteria, yeasts, plants, animals, and humans are frequently disturbed by various stresses, such as ultraviolet radiation, $\mathrm{pH}$, salinity, heat, and cold [12]. Cold stress responses in bacteria occur in two phases: a transient shock response and a continuous acclimation response [12]. When bacteria are exposed to low temperatures, they develop membrane modifications to maintain the membrane fluidity and structural integrity of macromolecule assemblies such as proteins and ribosomes [13-16]. Changes in temperature are a kind of stress that triggers protective mechanisms by gene expression and synthesis of a specific set of proteins known as heat shock proteins (HSPs) $[17,18]$. Generally, high temperatures create more interruption of the cellular metabolism, and require a higher level of stability of enzymes and other macromolecules to maintain cell survival [19].

Recently, several studies have reported that environmental agents such as UV radiation, nanomaterials, toxic agents, and heat and cold stress stimulate production of ROS in bacterial cells. ROS are reactive byproducts formed by the partial reduction of molecular oxygen, which arises when the concentration of active oxygen increases to a level that exceeds the cell's defense capacity [20]. The biological targets for these highly reactive oxygen species are DNA, RNA, proteins, and lipids. Among the biological molecules, lipids are major targets during oxidative stress [21]. In nature, living entities must face unfavorable conditions during their lives and reproductive processes [22]. For instance, bacteria have evolved various adaptive conditions by the synthesis of new proteins and they increase the activity of antioxidant systems under various stress conditions including temperature, $\mathrm{pH}$, oxygen concentration, and solar radiation. When high levels of ROS are present, several defense systems, such as superoxide dismutase, catalase, and peroxidase, maintain a steady-state level of ROS in order to protect the cell [23].

AuNPs have been used to treat diseases such as smallpox, skin ulcers, syphilis, and measles, and show anti-leishmanial and antimalarial activity [24,25]. Interestingly, gold compounds are used as anti-inflammatory agents due to their ability to inhibit expression of NF-kappaB and subsequent inflammatory reactions [26]. Recently, AuNPs were found to exhibit antioxidative properties by inhibiting the formation of ROS, scavenging free radicals, and increasing antioxidant defense enzymes in diabetes-induced mice [27]. Although biomedical research has focused extensively on AuNPs, to our knowledge, no studies have reported the protective role of AuNPs in cold or heat-induced oxidative stress in bacteria. 
Generally, Escherichia coli is considered a suitable model for stress responses, and is a particularly valuable model for exploring how single-celled organisms respond to environmental stresses [28]. In addition, it offers several advantages over other models due to the relative ease of modifying and manipulating it to study the mechanisms of oxidative stress. Furthermore, the absence of intracellular organelles makes possible a more accurate quantization of oxidants generated in the reactions [29]. Therefore, we have chosen E. coli as a model organism to elucidate the antioxidative properties of AuNPs in bacteria. To date, the protective effect of gold nanoparticles against cold- or heat-induced stress in bacteria is obscure. Therefore, the first aim of this study was the synthesis and characterization of gold nanoparticles using a novel probiotic bacterium called Bacillus clausii. The second aim was to investigate the effect of AuNPs on cold and heat-induced oxidative stress in E. coli.

\section{Results and Discussion}

\subsection{Synthesis and Characterization of AuNPs}

Whether they are prokaryotes or eukaryotes, biological organisms are known to defend themselves under unfavorable or extreme stress conditions such as extreme cold or heat. Fortunately, microbiologists and nanobiotechnologists can exploit microbes for the fabrication of nanomaterials or metal nanoparticles, as opposed to the environmentally toxic chemical method [3-5,30]. In this study, we explored a novel bacterium, B. clausii, for synthesis of AuNPs by the addition of selected culture supernatant to $1 \mathrm{mM}$ aqueous $\mathrm{HAuCl} 4$ at $40^{\circ} \mathrm{C}$. Within $2 \mathrm{~h}$ of incubation, the reaction mixture turned from yellow to a dark purple color (Figure 1A inset). This color formation is dependent on the excitation of surface plasmon vibrations of AuNPs [3,31,32]. It is primary evidence for the synthesis of AuNPs.

After primary characterization by observing visible color change, we performed a UV-vis measurement. The ultraviolet-visible (UV-vis) spectrum shows maximum absorption at $520 \mathrm{~nm}$, which is the typical surface plasmon resonance (SPR) band of AuNPs (Figure 1A). Observation of this peak, assigned to a surface plasmon, is well documented for various metal nanoparticles with sizes ranging from 2 to $100 \mathrm{~nm}$ [33]. The diffraction peaks of prepared AuNPs shown at $31.8^{\circ} \mathrm{C}$ corresponded to the (111) planes, respectively (Figure 1B). No extra peak was observed in the diffraction peaks, indicating that the biologically prepared AuNPs were highly purified without any contamination [3]. Next, FTIR analysis was performed to further show that biomolecules were responsible for synthesis and stabilizing of AuNPs by the culture supernatant of B. clausii. The AuNPs synthesized by the culture supernatant yielded strong bands at $1640 \mathrm{~cm}^{-1}$ (Figure 1C). These bands correspond to the amide I, II, and III bands of polypeptides/proteins, and are consistent with previous reports [3,34]. These peaks also represent the vibrational modes of $\mathrm{C}=\mathrm{C}$ double bonds of these molecules. Generally, the bands represented in the region between 1550 and $1650 \mathrm{~cm}^{-1}$ correspond to a secondary amine $\mathrm{NH}$ bend [35]. In addition, a prominent band was observed at $3400 \mathrm{~cm}^{-1}$, corresponding to the carbonyl and hydroxyl functional groups in alcohols and phenol derivatives [3,5]. Overall, the FTIR results show that surface capping of AuNPs synthesized by the water-soluble culture supernatant of bacteria is predominantly by proteins, which are favored in the biosynthesis of AuNPs.

Next, we examined EDS to identify the elemental composition of biologically prepared AuNPs. As shown in Figure 1D, the EDS profile shows a strong gold signal along with weak oxygen and carbon peaks, which may have originated from biomolecules of culture supernatant bound to AuNPs surfaces. The strong signal clearly indicates that the particle composition is gold, and indicates that the biomolecules of bacteria bound to the surface of the AuNPs originated from biological systems. The results of our experiments align with previous reports demonstrating synthesis of AuNPs using various biological materials such as chloroblasts [36], plant extracts [37], Bacillus flexus [32], and fungal extracts [3] as reducing and stabilizing agents.

Determination of monodispersity, uniformity, size, and surface morphology of prepared AuNPs is essential and indispensable for evaluation of the biological properties of synthesized AuNPs in 
bacterial or any cell line studies. Therefore, we performed size distribution and surface morphology analysis by DLS and TEM, respectively. DLS can provide a particular size distribution range as compared to TEM. As shown in Figure 1E, DLS analysis showed that the prepared AuNPs had an average size of $30 \mathrm{~nm}$, which was larger than the size measured by TEM due to Brownian motion. The TEM results clearly suggest that the particle size is $20 \mathrm{~nm}$, with a narrow size distribution, and that all the particles are significantly spherical in shape (Figure $1 \mathrm{~F}$ ), which precisely matches the profile of B. flexus [32]. However, other Bacillus species, such as B. licheniformis, also produce 10-100 nm nanocubes [31]. Previously, we showed that alpha amylase from $B$. licheniformis produced particles with an average size of 10-50 nm [8]. Fibrinolytic enzymes from B. cereus produced an average particle size of $20 \mathrm{~nm}$ [38]. Shewanella oneidensis produced discrete extracellular spherical gold nanocrystallites with an average size of around $12 \mathrm{~nm}$ [5].

A

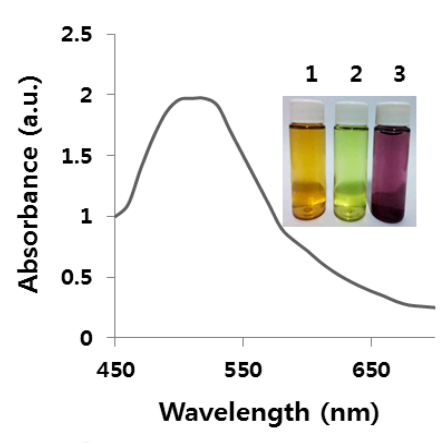

C

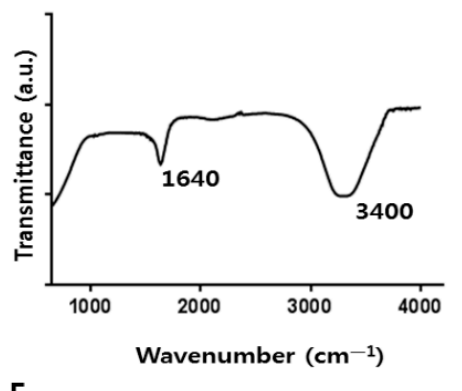

E
B

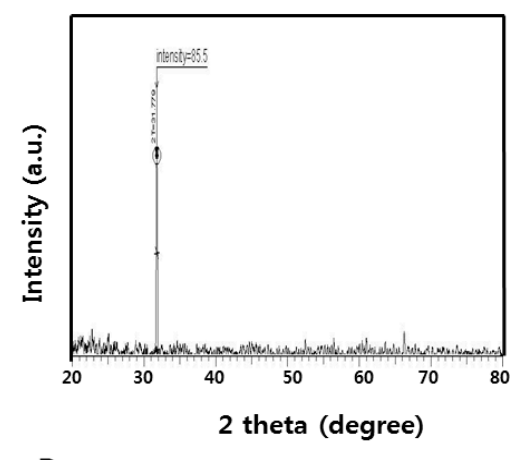

D

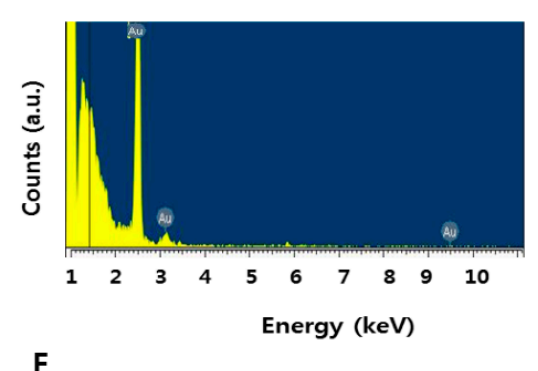

$\mathbf{F}$

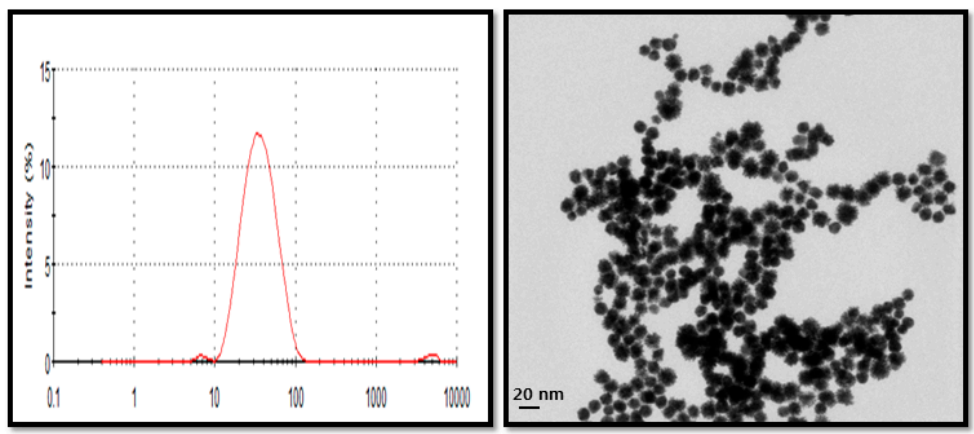

Figure 1. Synthesis and characterization of gold nanoparticles (AuNPs) using Bacillus clausii. (A) The absorption spectrum of AuNPs synthesized by B. clausii culture supernatant. The inset shows tubes containing samples of the $B$. clausii supernatant after exposure to $1 \mathrm{mM}$ aqueous $\mathrm{HAuCl}_{4}$ for $2 \mathrm{~h}$ (1), supernatant (2), $\mathrm{HAuCl}_{4}$ (3) $\mathrm{HAuCl}_{4}$ plus supernatant. The color of the solution turned from pale yellow to purple after $2 \mathrm{~h}$ of reaction time, indicating the formation of AuNPs; (B) X-ray diffraction spectrum of AuNPs; (C) FTIR spectra of AuNPs; (D) EDX spectra of AuNPs; (E) Size distribution analysis of AuNPs by DLS; (F) Size and surface morphology analysis of AuNPs by TEM. 


\subsection{Effect of AuNPs on E. coli}

In order to determine the antioxidative properties of AuNPs under cold- and heat-induced oxidative stress in E. coli, we first performed a cell viability assay to determine the biocompatibility effect of AuNPs on E. coli. AuNPs were added to LB medium at different concentrations. E. coli was exposed to $0-100 \mu \mathrm{g} / \mathrm{mL}$ for $12 \mathrm{~h}$ at $37^{\circ} \mathrm{C}$. At selected times, $100 \mu \mathrm{L}$ of medium was sampled, diluted, and cultured on LB agar plates, and its viability evaluated. CFU methods are accurate and conventional techniques for determining bacterial numbers with little influence from NPs [39]. CFU data were converted to percentages of cell viability, as shown in Figure 2A. The cell viability was decreased as the concentrations of the AuNPs increased from 20 to $100 \mu \mathrm{g} / \mathrm{mL}$. At $100 \mu \mathrm{g} / \mathrm{mL}$ of AuNPs, an approximately $96 \%$ reduction of cell viability as compared to the control sample was caused, as these concentrations represent the MIC values. The presence of AuNPs had no significant effect on cell viability up to the tested concentrations of $10 \mu \mathrm{g} / \mathrm{mL}$, and exhibited biocompatibility with E. coli. Although the biocompatible effect was observed up to $10 \mu \mathrm{g} / \mathrm{mL}$, we chose lower concentrations, such as $1 \mu \mathrm{g} / \mathrm{mL}$, for further experiments. It is important to choose lower concentrations to avoid any false-negative or false-positive misinterpretation of the results. Next, we evaluated whether a low concentration of AuNPs could influence the growth of cells under long periods of incubation. The cells were treated with AuNPs $(1 \mu \mathrm{g} / \mathrm{mL})$ and incubated for $21 \mathrm{~h}$. The results of this time-dependent experiment also show that AuNPs had no significant effect on cell viability (Figure 2B). Therefore, we selected $1 \mu \mathrm{g} / \mathrm{mL}$ for further experiments.

A

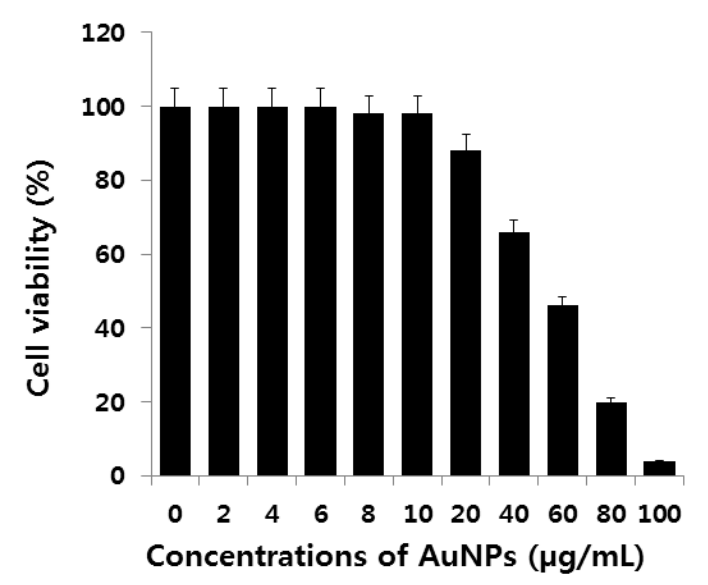

B

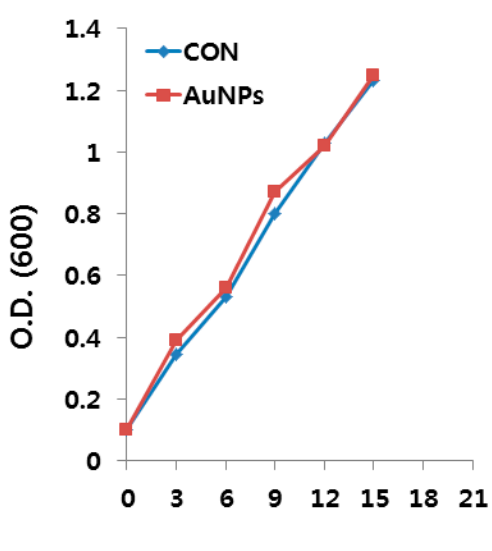

Time (h)

Figure 2. Effect of different concentrations of AuNPs and time on E. coli cell viability and growth. (A) E. coli cells were treated with AuNPs at various concentrations (from 0 to $100 \mu \mathrm{g} / \mathrm{mL}$ ) for $24 \mathrm{~h}$, and cell viability was determined by the CFU method. Data are shown as means and standard deviations calculated from three independent experiments; (B) Cells were incubated with $1 \mu \mathrm{g} / \mathrm{mL}$ of AuNPs. Samples were withdrawn at different points of growth, and the cells were centrifuged, washed with distilled water, and analyzed for growth at $600 \mathrm{~nm}$. Data are shown as means and standard deviations calculated from three independent experiments.

\subsection{AuNPs Ameliorate Cold- and Heat-Induced Cell Death}

Cold stress was induced by lowering the culture temperature from 37 to $4{ }^{\circ} \mathrm{C}$, and heat stress was induced by raising the culture temperature from 37 to $45^{\circ} \mathrm{C}$ for $2 \mathrm{~h}$. The cells were pre-incubated with AuNPs for $1 \mathrm{~h}$ before introduction to either cold or heat stress. Cells without AuNPs were used as controls. An additional control was kept at $37^{\circ} \mathrm{C}$ with and without AuNPs, because $37^{\circ} \mathrm{C}$ is the optimal temperature for $E$. coli growth. After the cells were exposed to the target temperatures in the 
presence or absence of AuNPs, they were brought to $37^{\circ} \mathrm{C}$. A viability assay was performed after 6 and $12 \mathrm{~h}$. The results clearly suggest that both cold and heat stress-induced cell death; however, the cells pretreated with AuNPs were able to rescue the cell death caused by cold and heat stress by at least $15 \%$ and $30 \%$ at $6 \mathrm{~h}$, and $45 \%$ and $65 \%$ at $12 \mathrm{~h}$ duration, respectively (Figure $3 \mathrm{~A}, \mathrm{~B}$ ). As expected, by increasing the time of incubation at $37^{\circ} \mathrm{C}$ after cold or heat stress, more cell viability was recovered in the presence of AuNPs. Interestingly, the rescue effect was more effective for heat stress than for cold. We found that $1 \mu \mathrm{g} / \mathrm{mL}$ of AuNPs suppressed the loss of viability, which suggests that AuNPs are highly protective to cells. The survival rate of heat stress-induced E. coli was $65 \%$ in the presence of AuNPs, even at a concentration of $1 \mu \mathrm{g} / \mathrm{mL}$. In comparison, cold stress caused a $45 \%$ survival rate at up to $1 \mu \mathrm{g} / \mathrm{mL}$ of AuNPs, and AuNPs showed less protection against cold- than against heat-induced stress. These data showed that the protective effect of AuNPs is more pronounced against heat stress than against cold.

A

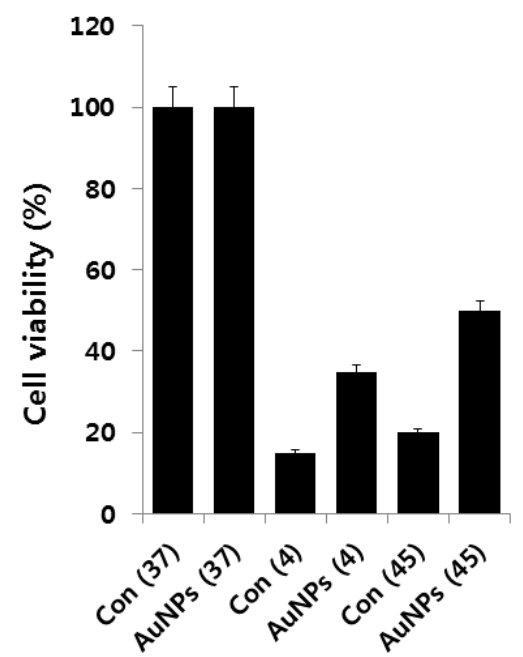

B

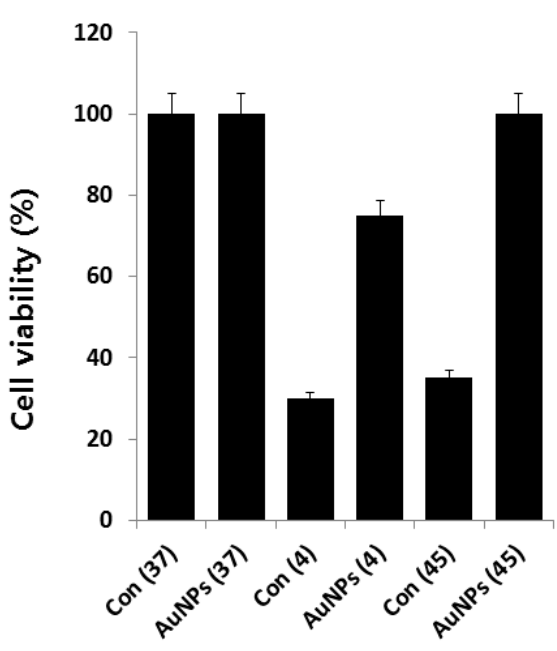

Figure 3. Effect of AuNPs on cold and heat stress-induced loss of viability. (A) E. coli cells were pre-incubated with AuNPs $(1 \mu \mathrm{g} / \mathrm{mL})$ for $1 \mathrm{~h}$, stressed at $4{ }^{\circ} \mathrm{C}$ or $45^{\circ} \mathrm{C}$, and subsequently recovered for $6 \mathrm{~h}$ at $37^{\circ} \mathrm{C}$. Cell viability rates were determined by the colony-counting method and expressed as a percentage of the control; (B) E. coli cells were pre-incubated with AuNPs $(1 \mu \mathrm{g} / \mathrm{mL})$ for $1 \mathrm{~h}$, stressed at $4{ }^{\circ} \mathrm{C}$ or $45^{\circ} \mathrm{C}$, and subsequently recovered for $12 \mathrm{~h}$ at $37^{\circ} \mathrm{C}$. Cell viability rates were determined by the colony-counting method and expressed as a percentage of the control. Data are shown as means and standard deviations calculated from three independent experiments. AuNP-treated groups showed statistically significant differences from the control group by Student's $t$-test $(p<0.05)$.

\subsection{Effect of AuNPs on Cold and Heat Stress-Induced ROS}

Heat stress is a major environmental stress that limits bacterial growth, metabolism, and reproduction. The physiology of bacterial response is dependent on temperature, and low temperatures may either allow growth to continue or, if sufficiently low, eventually lead to cell death [12]. ROS are often generated, depending on a variety of cellular conditions such as $\mathrm{pH}$ and temperature, and cell exposure to stress can lead to a drastic increase in ROS production [40]. In bacteria, proteins are major biological targets for oxidative damage within cells due to their high abundance and rapid rates of reaction with $\operatorname{ROS}[29,41,42]$. Oxidative stress is known to damage the cell membrane, proteins, DNA, and intracellular systems such as the respiratory system [43]. In the present study, we measured the level of ROS using DCFDA in cold and heat stress-treated E. coli as well as E. coli that were pre-treated with AuNPs. As shown in Figure 4A, after $2 \mathrm{~h}$ incubation, a significant increase in ROS was detected in cold and heat stress-induced E. coli, but not in the control group. Interestingly, AuNP-pretreated cells showed clear downregulation of ROS production. 

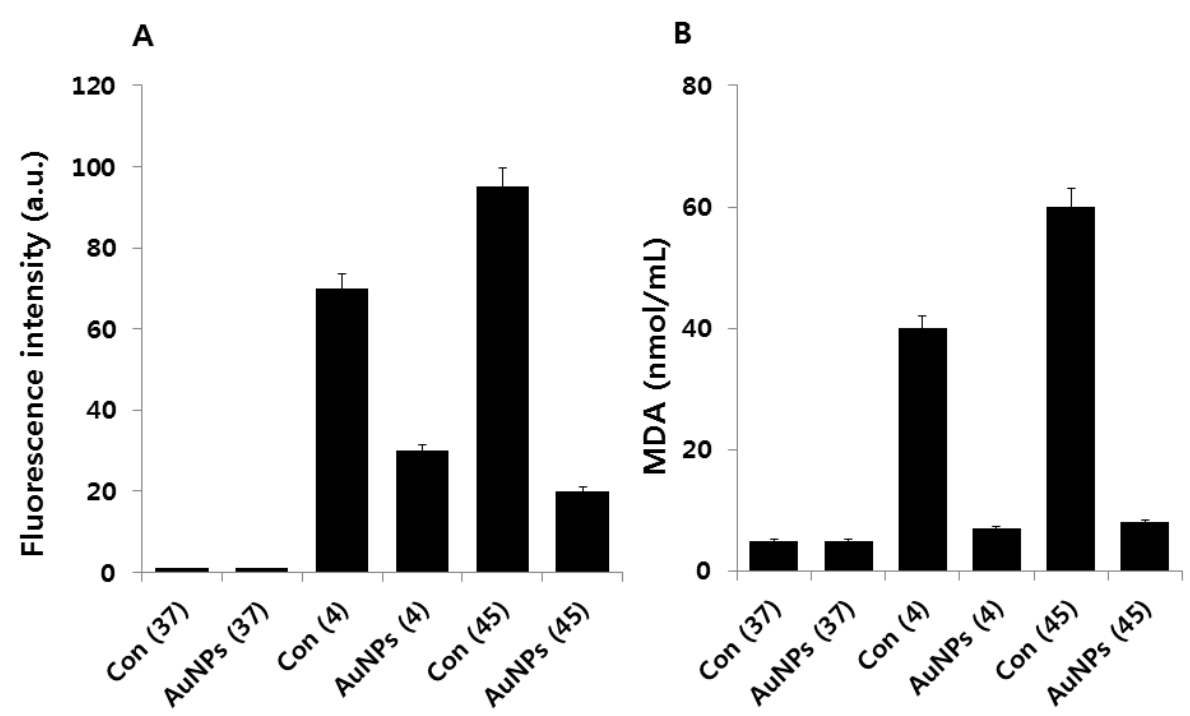

Figure 4. Effect of AuNPs on cold and heat stress-induced ROS generation. (A) E. coli cells were pre-incubated with AuNPs $(1 \mu \mathrm{g} / \mathrm{mL})$ for $1 \mathrm{~h}$, stressed at $4{ }^{\circ} \mathrm{C}$ or $45^{\circ} \mathrm{C}$, and subsequently recovered for $12 \mathrm{~h}$ at $37^{\circ} \mathrm{C}$. ROS generation was measured by DCFDA. Data are shown as means and standard deviations calculated from three independent experiments. AuNP-treated groups showed statistically significant differences from the control group by Student's $t$-test $(p<0.05)$; (B) E. coli cells were pre-incubated with AuNPs $(1 \mu \mathrm{g} / \mathrm{mL})$ for $1 \mathrm{~h}$, stressed at $4{ }^{\circ} \mathrm{C}$ or $45^{\circ} \mathrm{C}$, and subsequently recovered for $12 \mathrm{~h}$ at $37^{\circ} \mathrm{C}$. The MDA level was measured by TABARS assay. Data are shown as means and standard deviations calculated from three independent experiments. AuNP-treated groups showed statistically significant differences from the control group by Student's $t$-test $(p<0.05)$.

It has shown that high levels of free radicals or ROS can inflict direct damage on lipids. Lipid peroxidation is nothing but free radicals or non-radical species attacking lipids containing carbon-carbon double bonds [44]. MDA has been widely used as a convenient biomarker for lipid peroxidation of omega- 3 and omega- 6 fatty acids because of its facile reaction with thiobarbituric acid (TBA) [45]. Several studies have reported that MDA production is directly related to the concentration of generated ROS in the system [46]. To substantiate the relationship between ROS and MDA content in cold and heat stress-induced E. coli, we measured MDA content. As shown in Figure 4B, the levels of MDA were significantly higher in cold and heat stress-induced E. coli than in the controls. It is also noteworthy that the amount of MDA was 6- to 7-fold reduced by pretreatment with AuNPs relative to the stress-induced E. coli. These results suggest that the inhibition of bacterial growth due to cold or heat stress is attributable to ROS formation. Taken together, these results indicate that cell death is mediated by stress-activated ROS production, which creates an imbalance between oxidants and antioxidants in the cellular system.

\subsection{Effect of AuNPs on Metabolic Activity}

To corroborate the oxidative stress-induced damage to the respiratory system of the cells, LDH activity was measured. As compared to the E. coli in the control group, the stress-activated cells exhibited decreased levels of LDH, whereas LDH activity increased in cells treated with AuNPs (Figure 5A). LDH activity in stress-treated cells was significantly lower than that of the control group. These results indicate that ROS formed by cold and heat stress inhibit LDH, which in turn inhibits cell growth, viability, and reproduction. These results are consistent with earlier reports demonstrating LDH denaturation under stress conditions [47], where LDH was studied as a representative denatured protein under oxidative and heat stress conditions [48]. The inactivation and inhibition of LDH leads to increased leakage of proteins and other macromolecules. 


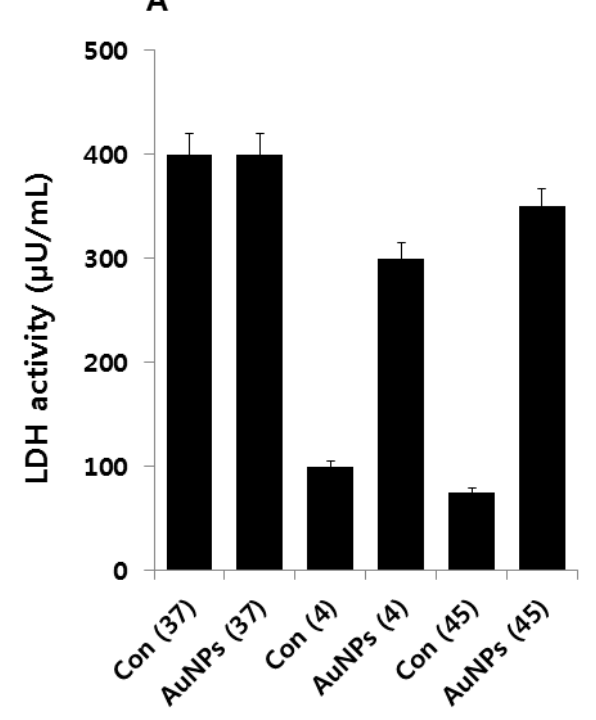

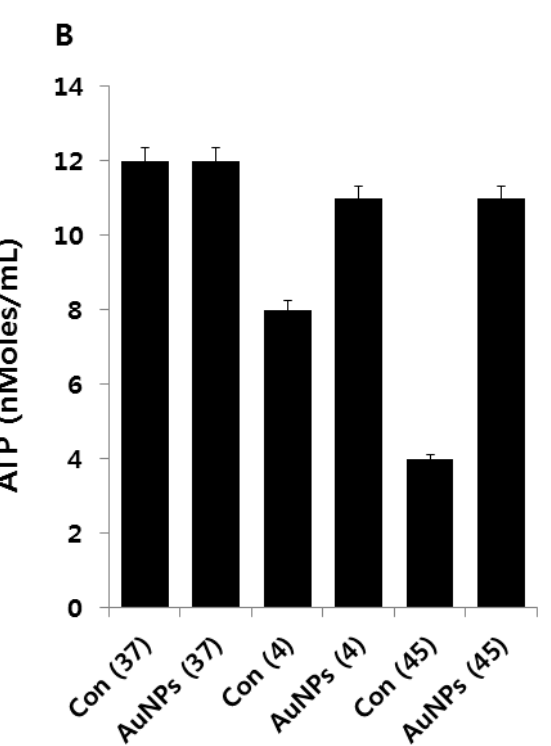

Figure 5. Effect of AuNPs on LDH activity and ATP levels. (A) E. coli cells were pre-incubated with AuNPs $(1 \mu \mathrm{g} / \mathrm{mL})$ for $1 \mathrm{~h}$, stressed at $4{ }^{\circ} \mathrm{C}$ or $45^{\circ} \mathrm{C}$, and subsequently recovered for $12 \mathrm{~h}$ at $37^{\circ} \mathrm{C}$. $\mathrm{LDH}$ activity was determined by measuring the reduction of $\mathrm{NAD}^{+}$to $\mathrm{NADH}$ and $\mathrm{H}^{+}$during the oxidation of lactate to pyruvate. Data are shown as means and standard deviations calculated from three independent experiments. AuNP-treated groups showed statistically significant differences from the control group by Student's $t$-test $(p<0.05)$; (B) E. coli cells were pre-incubated with AuNPs $(1 \mu \mathrm{g} / \mathrm{mL})$ for $1 \mathrm{~h}$, stressed at $4{ }^{\circ} \mathrm{C}$ or $45^{\circ} \mathrm{C}$, and subsequently recovered for $12 \mathrm{~h}$ at $37^{\circ} \mathrm{C}$. The ATP level was determined by measuring luminescence levels and comparing them to an ATP standard curve. Data are shown as means and standard deviations calculated from three independent experiments. AuNP-treated groups showed statistically significant differences from the control group by Student's $t$-test $(p<0.05)$.

Subsequently, we measured the level of ATP in cold and heat stress-induced E. coli and AuNPs-pretreated samples. ATP is a vital molecule for many biological functions, including survival, growth, and replication, and is involved as a signaling molecule [49]. We measured ATP levels in the cultures of all tested samples. The ATP levels in cold and heat stress-induced samples were lower than in the controls. Surprisingly, the level of ATP was not highly influenced by cold stress; conversely, heat stress influenced ATP levels dramatically. The ATP level in the supernatant of the AuNPs-pretreated samples was noticeably similar to the level in the controls (Figure 5B). The amelioration effect of AuNPs on extracellular ATP release needs further characterization; nevertheless, the rescue effect of AuNPs on ATP might affect additional functions in bacterial physiology in addition to its role as an energy supplier [49]. Overall, cold and heat stress play an important role in the metabolic activity of E. coli, which ultimately controls the growth and reproduction of these bacterial cells.

\subsection{Effect of AuNPs on Leakage of Proteins and Sugars}

Protein and sugar leakage from cells is a characteristic feature of heat damage in microorganisms. We observed that both heat and cold stress could enhance protein leakage by increasing the membrane permeability of E. coli cells (Figure 6A). Leakage from cells treated with cold temperatures was significantly higher than that of cells in the control group. Interestingly, cells pretreated with AuNPs showed significantly lower leakage than stress-induced cells did. Notably, our observations indicate that higher amounts of proteins leaked under stress conditions, suggesting that these increased the sensitivity of the cells more than the control or AuNP pretreatment. 
A

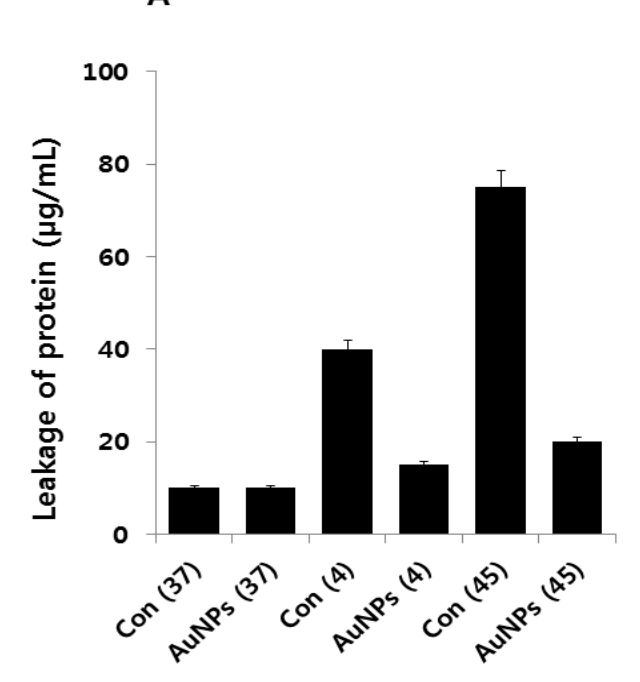

B

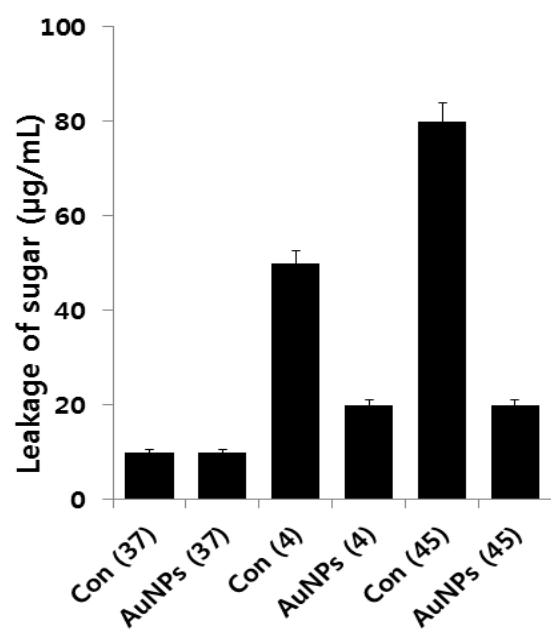

Figure 6. Effect of AuNPs on leakage of proteins and sugars. (A) E. coli cells were pre-incubated with AuNPs $(1 \mu \mathrm{g} / \mathrm{mL})$ for $1 \mathrm{~h}$, stressed at $4{ }^{\circ} \mathrm{C}$ or $45^{\circ} \mathrm{C}$, and subsequently recovered for $12 \mathrm{~h}$ at $37{ }^{\circ} \mathrm{C}$. Leakage proteins were measured using the Bradford assay; (B) The concentrations of sugars were measured. Data are shown as means and standard deviations calculated from three independent experiments. Treated groups showed statistically significant differences from the control group by Student's $t$-test $(p<0.05)$.

Next, the amount of sugars released into the cell suspension after each stress treatment was analyzed (Figure 6B). Cold and heat stress significantly affected the amount of sugar leakage as compared to the control. However, the amount of sugar leakage from cells treated with heat stress substantially differed from the control. These results indicate that in most of the stress-induced cells, intracellular materials were released into the cell suspension. The sugar release pattern under the two stress conditions was the reverse of the sugar release pattern by AuNPs; the amount of leaked sugars under both stress conditions was found to be much lower when AuNPs were present. As reported earlier, high temperatures or freezing may produce changes in the outer cell layers of bacteria, leading to morphological and structural changes (blebbing) and loss of outer membrane lipopolysaccharides (LPS) [50,51]. However, the protective mechanism of the action of AuNPs in the leakage of proteins and sugars is still unknown.

\subsection{Impact of AuNPs on GSH Levels}

We hypothesized that if cold or heat exerts oxidative stress, as evidenced by our results, this should affect cellular antioxidant metabolites such as glutathione (GSH). The tripeptide, GSH, and other thiols are major cellular antioxidants [52,53]. We measured GSH levels under two different stress conditions. Cells exposed to stress showed decreased levels of GSH; however, AuNPs pretreatment caused an immediate increase in GSH levels (Figure 7A). Furthermore, this was consistent with the results of this and other studies, indicating that heightened levels of oxidative stress are responsible for reduced levels of GSH in stress-exposed E. coli. Cellular levels of GSH began to recover coincident with reduction in internal oxidative stress and cellular recovery. These events also coincided with the induction of proteins likely to be involved in countering oxidative stress. Our findings are consistent with previous findings that in cells preadapted to low temperatures and grown at $20^{\circ} \mathrm{C}$, the concentration of GSH was 2.4 times lower than in cells grown at $37^{\circ} \mathrm{C}$ [54]. However, the detailed mechanism of the effect of AuNPs on GSH levels must be understood in order to establish any protective role for glutathione in defending against cold and heat stress. 
A

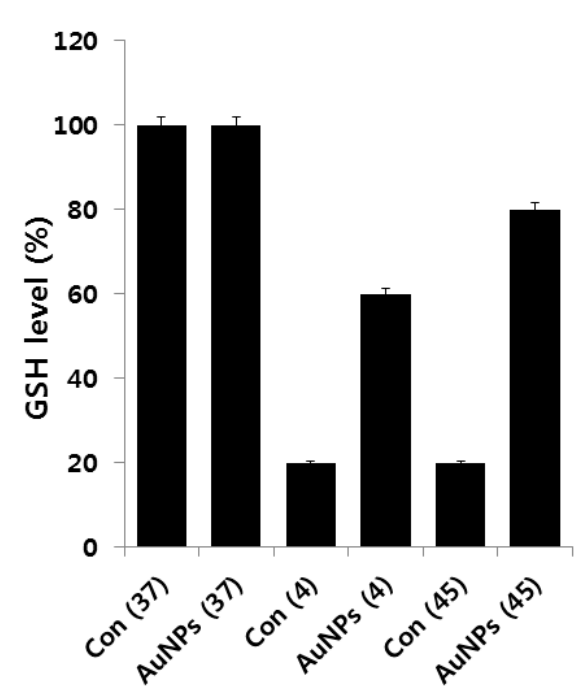

B

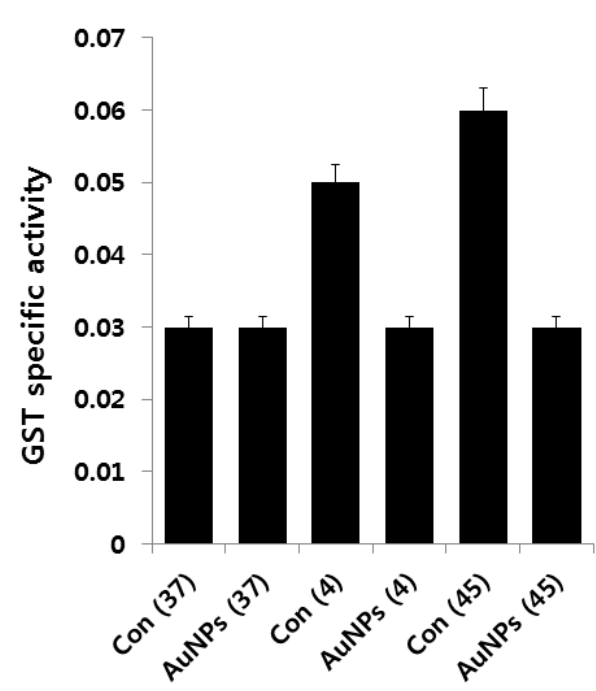

Figure 7. Effect of AuNPs on GSH and GST activity. (A) E. coli cells were pre-incubated with AuNPs $(1 \mu \mathrm{g} / \mathrm{mL})$ for $1 \mathrm{~h}$, stressed at $4{ }^{\circ} \mathrm{C}$ or $45^{\circ} \mathrm{C}$, and subsequently recovered for $12 \mathrm{~h}$ at $37{ }^{\circ} \mathrm{C}$. The amount of GSH was measured enzymatically in the clear supernatant based on the reduction of 5,5'-dithiobis-(2-nitrobenzoic acid) by the GSH reductase system; (B) GST activity was determined as described in the Materials and Methods section. Data are shown as means and standard deviations calculated from three independent experiments. Treated groups showed statistically significant differences from the control group by Student's $t$-test $(p<0.05)$.

To corroborate the results of our GSH analysis, we measured the activity of GST. GST is an enzyme whose activity is closely related to GSH; it is primarily involved in detoxification processes. Our aim was to measure GST activity to correlate the level of GSH concentration with GST. Total specific GST activity was measured, and the results revealed a distinct response for cold and heat stress (Figure 7B). Total GST activity increased from 0.03 units to 0.05 and 0.06 in cold and heat stress, respectively. When E. coli was grown in the presence of AuNPs, its GST activity was similar to that of the control. These results suggest that AuNPs maintain levels of both GSH and GST activity. Peters $e$ t al. reported that both glutathione reductase (GR) and glutathione S-transferase (GST) activity, together with the antioxidant compound, GSH, play major roles in the tolerance of a Pseudomonas aeruginosa strain to different herbicides [55]. The same scenario could exist in cold- and heat-induced oxidative stress in E. coli.

\subsection{Effect of AuNPs on SOD and Catalase Activity}

Exposure of living cells to moderate or high temperatures produces a small, selective number of highly conserved proteins called heat shock proteins [17]. SOD is known to be induced by oxidative stress imposed by dioxygen. Previous studies show that heat shock induces increased biosynthesis of MnSOD by E. coli [56]. To estimate the contribution of antioxidant systems to bacterial response to cold and heat stress, we examined the activity of SOD and CAT in the presence and absence of AuNPs. The obtained data suggest that both cold and heat stress decrease SOD (Figure 8A) and CAT activity (Figure 8B). Interestingly, cells pretreated with AuNPs show remarkable differences in the level of SOD and CAT activity as compared to cells exposed to cold or heat stress, which seems to be a response to increased intracellular production of $\mathrm{O}_{2}$ during heating, because it does not occur in the absence of dioxygen [56]. Thus, it appears that heating increases $\mathrm{O}_{2}$ and $\mathrm{H}_{2} \mathrm{O}_{2}$, thereby producing auto-oxidation within E. coli, possibly by disruption of the electron transport assemblies of the plasma membrane, and that increased $\mathrm{O}_{2}$ production elicits increased biosynthesis of MnSOD [56]. Conversely, Benov and 
Fridovich showed that, when a mid-log phase culture of the $\operatorname{sod} A \operatorname{sodB}$ strain was incubated at $43^{\circ} \mathrm{C}$, there was a moderate increase in $\mathrm{Cu}$ and $\mathrm{ZnSOD}$ over $3 \mathrm{~h}$, followed by a steep decline [57]. At $48^{\circ} \mathrm{C}$, a loss was observed due to the thermolabile properties of $\mathrm{Cu}$ and $\mathrm{ZnSOD}$. Our results are consistent with the findings of Benov and Fridovich [57].

A

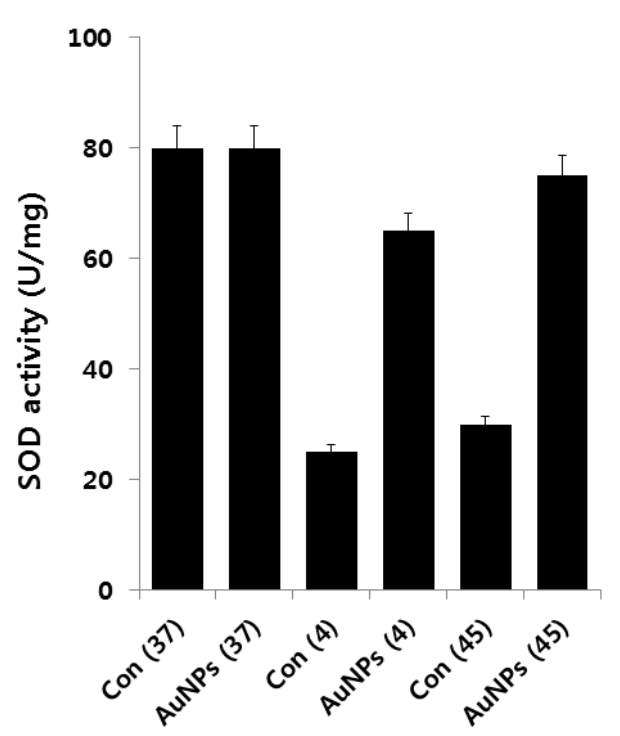

B

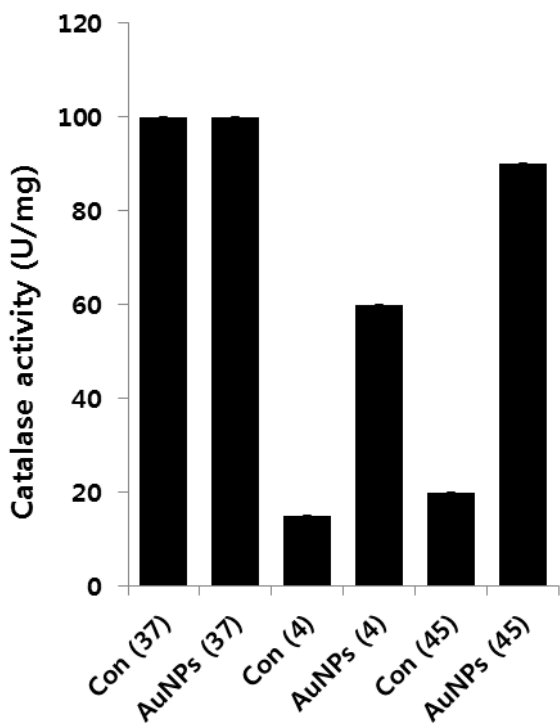

Figure 8. Effect of AuNPs on SOD and CAT activity. E. coli cells were pre-incubated with AuNPs $(1 \mu \mathrm{g} / \mathrm{mL})$ for $1 \mathrm{~h}$, stressed at $4{ }^{\circ} \mathrm{C}$ or $45^{\circ} \mathrm{C}$, and subsequently recovered for $12 \mathrm{~h}$ at $37^{\circ} \mathrm{C}$. SOD (A) and CAT activity (B) were measured as described in the Materials and Methods section. Data are shown as means and standard deviations calculated from three independent experiments. The treatment groups showed statistically significant differences from the control group by Student's $t$-test $(p<0.05)$.

The freezing process has been shown to generate free radicals in bacterial cells; however, the result depends on the level of available oxygen. The response of aerobically grown E. coli cells to cold stress induced by the rapid lowering of growth temperature from 37 to $4{ }^{\circ} \mathrm{C}$ was found to be basically the same as the oxidative stress response [54]. The decreased SOD and CAT activity in response to cold and heat stress were interpreted as oxidative, and both cold and heat stresses were attributable to a rise in the intracellular level of superoxide anions [54]. Furthermore, our results are in line with previous findings reporting that cold-shocked cells of $V$. cholera exhibited significantly lower levels of SOD activity than unstressed cells [58]. The data from our study and previous studies demonstrate that the differential responses of SOD and CAT activity are due to the temperature-shifting effect and that these enzymes are regulated by temperature, thus making E. coli more susceptible to oxygen radicals. Taken together, AuNPs may act as antioxidative agents that protect $E$. coli from both cold and heat-induced oxidative stress.

\section{Materials and Methods}

\subsection{Bacteria and Chemicals}

The E. coli strain used was DH5 $\alpha$ from our lab stock. DTNB [5,50-dithio-bis-(-2-nitrobenzoic acid)], and glutathione (GSH) were purchased from Sigma-Aldrich (St. Louis, MO, USA). Luria-Bertani (LB) agar was purchased from USB Corporation (Santa Clara, CA, USA). The $\mathrm{HAuCl}_{4}$, in vitro toxicology assay kit was purchased from Sigma-Aldrich. BacTiter-Glo ${ }^{\mathrm{TM}}$ Microbial Cell Viability Assay Reagent was purchased from Promega (Madison, WI, USA). All other chemicals were purchased from Sigma-Aldrich unless otherwise stated. 


\subsection{Media and Bacterial Growth Analysis}

Luria-Bertani (LB) media were prepared and used as previously described [59]. Bacillus clausii and E. coli cultures were first grown aerobically at $37^{\circ} \mathrm{C}$ in LB medium. The cells were harvested by centrifugation, washed twice with phosphate-buffered saline ( $\mathrm{pH}$ 7.3), and re-suspended in an appropriate fresh medium, such as LB, to the desired initial optical density (absorbance). Inoculated cultures were grown in a shaker $(120 \mathrm{rpm})$ in Erlenmeyer flasks (medium volume/flask volume of $1 / 10$ ) at $37^{\circ} \mathrm{C}$ until they reached the stationary phase. Growth was monitored spectrophotometrically by periodically measuring the absorbance at $600 \mathrm{~nm}$. The bacteria were routinely maintained on LB agar slants or plates at $37^{\circ} \mathrm{C}$ and preserved in glycerol stock solutions at $-70^{\circ} \mathrm{C}$. Unless otherwise stated, three independent trials were performed for all experiments.

\subsection{Extracellular Synthesis of AuNPs}

Extracellular synthesis of AuNPs was according to Murugan et al. [32]. B. clausii was inoculated into flasks containing sterile LB broth, and the flasks were incubated at $37^{\circ} \mathrm{C}$ for $24 \mathrm{~h}$ at $120 \mathrm{rpm}$. After the incubation period, the culture was centrifuged at 10,000 rpm and the supernatant used for the synthesis of AuNPs nanoparticles. The synthesis was carried out by incubating $1 \mathrm{mM} \mathrm{HAuCl} 4$ solution with bacterial culture supernatant for $2 \mathrm{~h}$ at $40{ }^{\circ} \mathrm{C}$. The extracellular synthesis of AuNPs was monitored by visual inspection of the test tubes for a change in the color of the culture medium from a clear, light yellow to reddish purple, and the synthesis of AuNPs was confirmed by the presence of the AuNPs peak in the UV-vis spectrum.

\subsection{Characterization of $A u N P S$}

Characterization of synthesized AuNPs particles was carried out according to the methods described previously. The AuNPs were primarily characterized by UV-visible spectroscopy. UV-vis spectra were obtained using an OPTIZEN POP spectrophotometer (Mecasys Co., Seoul, Korea) at Konkuk University, South Korea. The particle size of the dispersions was measured by a Zetasizer Nano ZS90 (Malvern Instruments, Ltd., Malvern, UK). X-ray diffraction (XRD) analyses were carried out on an X-ray diffractometer (Bruker D8 DISCOVER; Bruker AXS, Madison, MA, USA). The high-resolution XRD patterns were measured at $3 \mathrm{~kW}$ with a $\mathrm{Cu}$ target, using a scintillation counter $(\lambda=1.5406 \AA)$ at $40 \mathrm{kV}$ and $40 \mathrm{~mA}$, and were recorded in the range of $2 \theta=5^{\circ}-80^{\circ}$. Further characterization of changes in the surface and surface composition was performed by Fourier transform infrared (FTIR) spectroscopy (PerkinElmer Spectroscopy GX, PerkinElmer Inc., Waltham, MA, USA). Transmission electron microscopy (TEM) using a JEM-1200EX microscope (JEOL Ltd, Tokyo, Japan) was performed to determine the size and morphology of the AuNPs. TEM images of AuNPs were obtained at an accelerating voltage of $300 \mathrm{kV}$. The presence of Au metals in the sample was analyzed by energy-dispersive X-ray analysis (EDX).

\subsection{Heat and Cold Stress Treatments}

For the cold stress treatments, cultures of E. coli $(\mathrm{OD} 600 \mathrm{~nm}=0.5)$ were transferred from $37^{\circ} \mathrm{C}$ to $4{ }^{\circ} \mathrm{C}$ and then incubated for $2 \mathrm{~h}$. For heat stress treatments, cultures of $E$. coli $(\mathrm{OD} 600 \mathrm{~nm}=0.5)$ were transferred from $37^{\circ} \mathrm{C}$ to a $45^{\circ} \mathrm{C}$ water bath, and then incubated for $2 \mathrm{~h}$. Cells not exposed to cold or heat stress served as controls. The cells grown at $37^{\circ} \mathrm{C}$ served as another control. For AuNPs treatments, cells were pre-treated with AuNPs $(1 \mu \mathrm{g} / \mathrm{mL})$ for $1 \mathrm{~h}$ and then exposed to the appropriate treatment temperature $\left(37^{\circ} \mathrm{C}, 4^{\circ} \mathrm{C}\right.$, or $\left.45^{\circ} \mathrm{C}\right)$. The temperature was maintained for $2 \mathrm{~h}$. Subsequent recovery involved return to $37^{\circ} \mathrm{C}$ after cold and heat stress. After cold or heat treatment, the cells were removed, the medium was changed, and the cells were allowed to recover from heat stress for 6 or $12 \mathrm{~h}$. Bacterial cell growth was monitored by both CFU and $\mathrm{OD}_{600}$ measurement. Growth under cold $\left(4^{\circ} \mathrm{C}\right)$ and heat stress conditions $\left(45^{\circ} \mathrm{C}\right)$ was also examined using the same method. To compare growth under stress with growth under non-stress conditions, the strains were grown at $37^{\circ} \mathrm{C}$ in the 
presence and absence of AuNPs; such conditions are referred to as control conditions throughout this paper. To determine the effect of AuNPs on viability and other biochemical assays, the strains were also grown in the absence of AuNPs at $4{ }^{\circ} \mathrm{C}$ and $45^{\circ} \mathrm{C}$ without prior pretreatment. All experiments were repeated at least three times.

\subsection{Bacterial Cell Lysate Preparation}

To prepare bacterial cell lysates, cells were grown and centrifuged at $4{ }^{\circ} \mathrm{C}$ for $10 \mathrm{~min}$ at $5000 \mathrm{rpm}$. The pellet was then washed with PBS and re-suspended in bacterial lysis buffer, followed by the addition of lysozyme and incubation at $4{ }^{\circ} \mathrm{C}$ for $4 \mathrm{~h}$ before probe sonication for $5 \mathrm{~min}$. Cell debris was removed by centrifugation at 10,000 rpm, and the supernatant was collected and used for enzyme assay [60].

\subsection{Effect of AuNPs on E. coli}

Assessment of AuNPs on microbial toxicity was performed as described previously [61]. To examine the effect of AuNPs on the growth of E. coli, overnight cultures were centrifuged at $6000 \mathrm{rpm}$ for $5 \mathrm{~min}$, washed with 1x PBS, and the pellet re-suspended in saline buffer. Finally, the OD600 of the sample was adjusted to 0.1 . The cells $\left(10^{6}\right)$ were exposed to different concentrations of AuNPs in 96-well round-bottom plates, in triplicate. Bacteria were harvested at the indicated times or dose responses, and the number of CFUs was determined. Medium and medium with AuNPs served as controls. All samples were plated in triplicate, and values of three independent experiments were averaged.

\subsection{Measurement of Reactive Oxygen Species (ROS)}

ROS generation was measured according to the method described earlier, using $2^{\prime}, 7^{\prime}$-dichlorofluorescein diacetate (DCFDA) [43]. Bacterial cells $\left(10^{6} \mathrm{CFU} / \mathrm{mL}\right)$ were treated at the required temperature for $2 \mathrm{~h}$, with AuNPs and without AuNPs. After incubation, the cells were centrifuged at $4{ }^{\circ} \mathrm{C}$ for $30 \mathrm{~min}$ at $300 \times g$, and each supernatant was treated with $100 \mu \mathrm{M}$ DCFDA for $1 \mathrm{~h}$. The ROS formed in the sample were detected at $485 / 20 \mathrm{~nm}$ of fluorescence excitation wavelength and $528 / 20 \mathrm{~nm}$ of emission wavelength using a fluorescence multi-detection reader (Bio Tek, Winooski, VT, USA).

\subsection{Measurement of $M D A$}

The concentration of MDA generated in the culture media from the cells incubated at the required temperature was determined using thiobarbituric acid-reactive substances assay as described previously, with suitable modifications [62]. Briefly, an aliquot of $1 \mathrm{~mL}$ of culture media was collected from the treated cells and 10\% SDS was added and swirled vigorously. Next, $2 \mathrm{~mL}$ of freshly prepared thiobarbituric acid (TBA) was added to the above mix and incubated at $95{ }^{\circ} \mathrm{C}$ for $60 \mathrm{~min}$. The reaction was then cooled to room temperature and centrifuged at $5000 \mathrm{rpm}$ for $10 \mathrm{~min}$, and the OD of the supernatant was measured at $530 \mathrm{~nm}$.

\subsection{Measurement of $L D H$}

For LDH assay, bacterial cells $\left(10^{6} \mathrm{CFU} / \mathrm{mL}\right)$ were treated at the required temperature for $2 \mathrm{~h}$, with and without AuNPs. After incubation, the cells were centrifuged at $4{ }^{\circ} \mathrm{C}$ for $30 \mathrm{~min}$ at $300 \times g$, and then each supernatant was discarded. The pellet was washed twice and treated with LDH reaction solution in a microplate [43]. The plate was incubated with gentle shaking on an orbital shaker for $30 \mathrm{~min}$ at room temperature. After incubation, the O.D. of the plate was determined at $490 \mathrm{~nm}$. 


\subsection{Measurement of ATP Levels}

Measurement of ATP levels in the bacterial culture supernatant was according to Mempin et al. [49] and the manufacturer's instructions for BacTiter-Glo ${ }^{\mathrm{TM}}$ Microbial Cell Viability Assay Reagent (Promega). This is a luciferase-based assay, and the ATP level is determined by measuring luminescence levels and comparing to an ATP standard curve. Briefly, $100 \mu \mathrm{L}$ of culture supernatant from the control or cells exposed to stress was mixed with an equal volume of BacTiter-Glo ${ }^{\mathrm{TM}}$ Microbial Cell Viability Assay Reagent in a 96-well opaque plate and incubated at room temperature for $5 \mathrm{~min}$. After incubation, the luminescence was read in a SpectraMax M2 plate reader (Molecular Devices, Sunnyvale, CA, USA).

\subsection{Assay for the Leakage of Proteins and Sugars}

Protein and sugar leakage in bacterial cells was determined as described previously [63]. Bacterial cells $\left(10^{6} \mathrm{CFU} / \mathrm{mL}\right)$ were treated at the required temperature for $2 \mathrm{~h}$, with and without AuNPs. Each culture was incubated in a shaking incubator at $37^{\circ} \mathrm{C}$ for $4 \mathrm{~h}$. Culture samples ( $1 \mathrm{~mL}$ from each culture) were centrifuged at $4^{\circ} \mathrm{C}$ for $30 \mathrm{~min}$ at $10,000 \mathrm{rpm}$, and the supernatant was frozen at $-20^{\circ} \mathrm{C}$ before being used to estimate the protein and sugar levels.

\subsection{Estimation of GSH Level}

To enzymatically determine GSH levels, cells were incubated at the required temperature with or without AuNPs for $2 \mathrm{~h}$. Cells were pelleted by 5-min centrifugation at 10,000 rpm, washed with PBS, and lysed. The lysate was prepared as described above. The amount of GSH was measured enzymatically in the clear supernatant, based on the reduction of 5,5'-dithiobis-(2-nitrobenzoic acid) by the GSH reductase system, as described previously [64]. All samples were prepared in triplicate. DTNB (Ellman's reagent, 5,50-dithio-bis-(2-nitrobenzoic acid), Sigma-Aldrich) was added to the mixtures to yield a yellow product. The absorbance at $412 \mathrm{~nm}$ was measured using a spectrophotometer.

\subsection{Determination of GST Total Activity}

GST activity was followed as described previously [55], with suitable modifications. GST was assayed spectrophotometrically at $37^{\circ} \mathrm{C}$ in a mixture containing $900 \mathrm{~mL} 100 \mathrm{mM}$ potassium phosphate buffer (pH 6.5), 25 mL 40 mM 1-chloro-2,4-dinitrobenzene (CDNB), $50 \mathrm{~mL} 1 \mathrm{mM} \mathrm{GSH,} \mathrm{and} 25 \mu \mathrm{L}$ enzyme extract. The reaction mixture was followed by monitoring the increase in absorbance at $340 \mathrm{~nm}$ over $5 \mathrm{~min}$. GST activity was expressed as $\mu \mathrm{mol} / \mathrm{min} / \mathrm{mg}$ protein.

\subsection{Determination of Superoxide Dismutase and Catalase Activity}

Catalase activity was measured using a protocol described previously [65] with suitable modifications. In a typical reaction, a mixture of $500 \mu \mathrm{L} 0.1 \mathrm{M}$ phosphate buffer (pH 7.5) and $500 \mu \mathrm{L}$ freshly prepared $0.9 \%$ (volume percent) $\mathrm{H}_{2} \mathrm{O}_{2}$ solution was prepared. Bacterial cell lysate $(100 \mu \mathrm{L})$ was added to the mixture and incubated for $3 \mathrm{~min}$. The reaction was terminated by dropwise addition of $2 \mathrm{~N} \mathrm{H}_{2} \mathrm{SO}_{4}$. The unreacted $\mathrm{H}_{2} \mathrm{O}_{2}$ was titrated with $0.1 \mathrm{~N} \mathrm{KMnO}_{4}$. Boiled bacterial cell lysate with or without AuNPs was used as a blank. Enzyme activity was calculated as described previously. SOD activity was measured as described previously [66] using an SOD Assay Kit (Sigma, St. Louis, MO, USA, 19160). Specific enzyme activity was calculated from the enzyme activity and total protein concentration in the bacterial cell lysate, as determined by the Bradford method [60].

\section{Conclusions}

Gold nanoparticles are tremendously useful for diagnostic and therapeutic purposes due to their unique physical, chemical, and biological properties. AuNPs have shown nontoxic and protective effects in several models, including bacteria. However, thus far, no studies have reported the ameliorative effect of AuNPs on oxidative stress induced by cold or heat stress in E. coli. Stress 
includes any parameters that can influence biological systems, and eventually affects viability, growth, metabolism, and reproduction. The stress response of E. coli is a complex, vigorous, and adaptable process. Therefore, we first demonstrated the synthesis of AuNPs using a novel bacterium called Bacillus clausii. Second, we investigated the antioxidative properties of biologically prepared AuNPs in E. coli induced by cold and heat stress. These results of this study indicate that these two different stress responses significantly influence cell viability and metabolic activity as well as the balance of pro- and antioxidant levels at the cellular level. Interestingly, E. coli cells pre-treated with AuNPs were able to recover from stress by inducing defense mechanisms, including suppression of ROS and MDA, leakage of proteins and sugars, and increased levels of LDH and ATP. Furthermore, cells pretreated with AuNPs showed increased levels of antioxidants such as GSH, GST, SOD, and CAT. These potential roles of AuNPs in preventing oxidative stress and its adverse effects as induced by cold and heat stress conditions could open up a new avenue for preventing disease caused by stress-tolerant bacteria. In fact, the activation of stress responses is an important factor for antimicrobial resistance development. An increased understanding of the mechanisms and regulation of the stress adaptation of E. coli by AuNPs will provide information for pathogenic control, improve the effectiveness of design of novel control methods, and increase the microbial safety of foods. It is a valuable model for therapeutic targets and methods of targeting them using nontoxic, biocompatible, antioxidative agents.

Acknowledgments: This paper was supported by the KU-Research Professor Program of Konkuk University. This study was also supported by the Science and Technology Research Program of the Department of Education of Hubei Province, China (D20151701).

Author Contributions: S.G. came up with the idea and participated in the design, preparation and characterization of gold nanoparticles, and writing of the manuscript. X.-F.Z. performed all biochemical assays. W.S. analyzed the data. All authors read and approved the final manuscript.

Conflicts of Interest: The authors declare no conflict of interest.

\section{References}

1. Daniel, M.C.; Astruc, D. Gold nanoparticles: Assembly, supramolecular chemistry, quantum-size-related properties, and applications toward biology, catalysis, and nanotechnology. Chem. Rev. 2004, 104, 293-346. [CrossRef] [PubMed]

2. Huang, X.; El-Sayed, I.H.; El-Sayed, M.A. Applications of gold nanorods for cancer imaging and photothermal therapy. Methods Mol. Biol. 2010, 624, 343-357. [PubMed]

3. Gurunathan, S.; Han, J.; Park, J.H.; Kim, J.H. A green chemistry approach for synthesizing biocompatible gold nanoparticles. Nanoscale Res. Lett. 2014, 9. [CrossRef] [PubMed]

4. Murugan, K.; Senthilkumar, B.; Senbagam, D.; Al-Sohaibani, S. Biosynthesis of silver nanoparticles using Acacia leucophloea extract and their antibacterial activity. Int. J. Nanomed. 2014, 9, 2431-2438.

5. Suresh, A.K.; Pelletier, D.A.; Wang, W.; Broich, M.L.; Moon, J.W.; Gu, B.; Allison, D.P.; Joy, D.C.; Phelps, T.J.; Doktycz, M.J. Biofabrication of discrete spherical gold nanoparticles using the metal-reducing bacterium Shewanella oneidensis. Acta Biomater. 2011, 7, 2148-2152. [CrossRef] [PubMed]

6. Nair, B.; Pradeep, T. Coalescence of nanoclusters and formation of submicron crystallites assisted by Lactobacillus strains. Cryst. Growth Des. 2002, 2, 293-298. [CrossRef]

7. Sriram, M.I.; Kalishwaralal, K.; Gurunathan, S. Biosynthesis of silver and gold nanoparticles using Bacillus licheniformis. Methods Mol. Biol. 2012, 906, 33-43. [PubMed]

8. Kalishwaralal, K.; Deepak, V.; RamKumarPandian, S.; Kottaisamy, M.; BarathmaniKanth, S.; Kartikeyan, B.; Gurunathan, S. Biosynthesis of silver and gold nanoparticles using Brevibacterium casei. Colloids Surf. B Biointerfaces 2010, 77, 257-262. [CrossRef] [PubMed]

9. Gupta, S.; Bector, S. Biosynthesis of extracellular and intracellular gold nanoparticles by Aspergillus fumigatus and A. flavus. Antonie Van Leeuwenhoek 2013, 103, 1113-1123. [CrossRef] [PubMed]

10. Philip, D. Biosynthesis of Au, Ag and Au-Ag nanoparticles using edible mushroom extract. Spectrochim. Acta A Mol. Biomol. Spectrosc. 2009, 73, 374-381. [CrossRef] [PubMed]

11. Segal, G.; Ron, E.Z. Heat shock activation of the groESL operon of Agrobacterium tumefaciens and the regulatory roles of the inverted repeat. J. Bacteriol. 1996, 178, 3634-3640. [PubMed] 
12. Panoff, J.M.; Thammavongs, B.; Guéguen, M.; Boutibonnes, P. Cold stress responses in mesophilic bacteria. Cryobiology 1998, 36, 75-83. [CrossRef] [PubMed]

13. Russell, J.B.; Strobel, H.J.; Martin, S.A. Strategies of nutrient transport by ruminal bacteria. J. Dairy Sci. 1990, 73, 2996-3012. [CrossRef]

14. Jaenicke, R. Protein stability and molecular adaptation to extreme conditions. Eur. J. Biochem. 1991, 202, 715-728. [CrossRef] [PubMed]

15. Berry, E.D.; Foegeding, P.M. Cold temperature adaptation and growth of microorganisms. J. Food Prot. 1997, $60,1583-1594$.

16. Chung, H.J.; Bang, W.; Drake, M.A. Stress response of Escherichia coli. Compr. Rev. Food Sci. Food Saf. 2006, 5, 52-64. [CrossRef]

17. Lindquist, S. The heat-shock response. Annu. Rev. Biochem. 1986, 55, 1151-1191. [PubMed]

18. Schlesinger, M.J. Heat shock proteins. J. Biol. Chem. 1990, 265, 12111-12114. [PubMed]

19. Price, P.B.; Sowers, T. Temperature dependence of metabolic rates for microbial growth, maintenance, and survival. Proc. Natl. Acad. Sci. USA 2004, 101, 4631-4636. [CrossRef] [PubMed]

20. Cabiscol, E.; Tamarit, J.; Ros, J. Oxidative stress in bacteria and protein damage by reactive oxygen species. Int. Microbiol. 2000, 3, 3-8. [PubMed]

21. Cabiscol, E.; Piulats, E.; Echave, P.; Herrero, E.; Ros, J. Oxidative stress promotes specific protein damage in Saccharomyces cerevisiae. J. Biol. Chem. 2000, 275, 27393-27398. [CrossRef] [PubMed]

22. Smirnova, M.G. Study of physiological and toxic effects of a sweetening agent stevioside (review of the literature). Vopr. Pitan. 2001, 70, 41-44. [PubMed]

23. Gort, A.S.; Imlay, J.A. Balance between endogenous superoxide stress and antioxidant defenses. J. Bacteriol. 1998, 180, 1402-1410. [PubMed]

24. Chen, W.; Lu, Z.; Li, C.M. Sensitive human interleukin 5 impedimetric sensor based on polypyrrole-pyrrolepropylic acid-gold nanocomposite. Anal. Chem. 2008, 80, 8485-8492. [CrossRef] [PubMed]

25. Vieites, M.; Smircich, P.; Guggeri, L.; Marchán, E.; Gómez-Barrio, A.; Navarro, M.; Garat, B.; Gambino, D. Synthesis and characterization of a pyridine-2-thiol N-oxide gold (I) complex with potent antiproliferative effect against Trypanosoma cruzi and Leishmania sp. insight into its mechanism of action. J. Inorg. Biochem. 2009, 103, 1300-1306. [CrossRef] [PubMed]

26. Jeon, B.H.; Khanday, F.; Deshpande, S.; Haile, A.; Ozaki, M.; Irani, K. Tie-ing the antiinflammatory effect of angiopoietin-1 to inhibition of NF-kappaB. Circ. Res. 2003, 92, 586-588. [CrossRef] [PubMed]

27. Barathmanikanth, S.; Kalishwaralal, K.; Sriram, M.; Pandian, S.R.; Youn, H.S.; Eom, S.; Gurunathan, S. Anti-oxidant effect of gold nanoparticles restrains hyperglycemic conditions in diabetic mice. J. Nanobiotechnol. 2010, 8. [CrossRef] [PubMed]

28. Boor, K.J. Bacterial stress responses: What doesn't kill them can make then stronger. PLoS Biol. 2006, 4, e23. [CrossRef]

29. Vatansever, F.; de Melo, W.C.; Avci, P.; Vecchio, D.; Sadasivam, M.; Gupta, A.; Chandran, R.; Karimi, M.; Parizotto, N.A.; Yin, R.; et al. Antimicrobial strategies centered around reactive oxygen species-bactericidal antibiotics, photodynamic therapy, and beyond. FEMS Microbiol. Rev. 2013, 37, 955-989. [CrossRef] [PubMed]

30. Suresh, A.K.; Pelletier, D.A.; Wang, W.; Moon, J.W.; Gu, B.; Mortensen, N.P.; Allison, D.P.; Joy, D.C.; Phelps, T.J.; et al. Silver nanocrystallites: Biofabrication using Shewanella oneidensis, and an evaluation of their comparative toxicity on gram-negative and gram-positive bacteria. Environ. Sci. Technol. 2010, 44, 5210-5215. [CrossRef] [PubMed]

31. Kalishwaralal, K.; Deepak, V.; Pandian, S.R.K.; Gurunathan, S. Biological synthesis of gold nanocubes from Bacillus licheniformis. Bioresour. Technol. 2009, 100, 5356-5358. [CrossRef] [PubMed]

32. Murugan, M.; Anthony, K.J.P.; Jeyaraj, M.; Rathinam, N.K.; Gurunathan, S. Biofabrication of gold nanoparticles and its biocompatibility in human breast adenocarcinoma cells (MCF-7). J. Ind. Eng. Chem. 2014, 20, 1713-1719. [CrossRef]

33. Sastry, M.; Patil, V.; Sainkar, S.R. Electrostatically controlled diffusion of carboxylic acid derivatized silver colloidal particles in thermally evaporated fatty amine films. J. Phys. Chem. B 1998, 102, 1404-1410. [CrossRef] 
34. Shankar, S.S.; Ahmad, A.; Pasricha, R.; Sastry, M. Bioreduction of chloroaurate ions by Geranium leaves and its endophytic fungus yields gold nanoparticles of different shapes. J. Mater. Chem. 2003, 13, 1822-1826. [CrossRef]

35. Gole, A.; Dash, C.; Soman, C.; Sainkar, S.R.; Rao, M.; Sastry, M. On the preparation, characterization, and enzymatic activity of fungal protease-gold colloid bioconjugates. Bioconjug. Chem. 2001, 12, 684-690. [CrossRef] [PubMed]

36. Zhang, Y.X.; Zheng, J.; Gao, G.; Kong, Y.F.; Zhi, X.; Wang, K.; Zhang, X.Q.; Cui, D.X. Biosynthesis of gold nanoparticles using chloroplasts. Int. J. Nanomed. 2011, 6, 2899-2906. [CrossRef] [PubMed]

37. Elia, P.; Zach, R.; Hazan, S.; Kolusheva, S.; Porat, Z.; Zeiri, Y. Green synthesis of gold nanoparticles using plant extracts as reducing agents. Int. J. Nanomed. 2014, 9, 4007-4021.

38. Deepak, V.; Umamaheshwaran, P.S.; Guhan, K.; Nanthini, R.A.; Krithiga, B.; Jaithoon, N.M.; Gurunathan, S. Synthesis of gold and silver nanoparticles using purified URAK. Coll. Surf. B Biointerfaces 2011, 86, 353-358. [CrossRef] [PubMed]

39. Zhou, Y.; Kong, Y.; Kundu, S.; Cirillo, J.D.; Liang, H. Antibacterial activities of gold and silver nanoparticles against Escherichia coli and bacillus Calmette-Guérin. J. Nanobiotechnol. 2012, 10, 19. [CrossRef] [PubMed]

40. Schmitt, F.J.; Renger, G.; Friedrich, T.; Kreslavksi, V.D.; Zharmukhadmedov, S.K.; Los, D.A.; Kuznetsov, V.V.; Allakhverdiev, S.I. Reactive oxygen species: Re-evaluation of generation, monitoring and role in stress-signaling in phototrophic organisms. Biochim. Biophys. Acta 2014, 1837, 385-848. [CrossRef] [PubMed]

41. Butterfield, D.A.; Dalle-Donne, I. Redox proteomics. Antioxid. Redox Signal 2012, 17, 1487-1489. [CrossRef] [PubMed]

42. Davies, M.J. Reactive species formed on proteins exposed to singlet oxygen. Photochem. Photobiol. Sci. 2004, 3, 17-25. [CrossRef] [PubMed]

43. Kim, S.H.; Lee, H.S.; Ryu, D.S.; Choi, S.J.; Lee, D.S. Antibacterial activity of silver-nanoparticles against staphylococcus aureus and Escherichia coli. Korean J. Microbiol. Biotechnol. 2011, 39, 77-85.

44. Yin, H.; Xu, L.; Porter, N.A. Free radical lipid peroxidation: Mechanisms and analysis. Chem. Rev. 2011, 111, 5944-5972. [CrossRef] [PubMed]

45. Esterbauer, H.; Cheeseman, K.H. Determination of aldehydic lipid peroxidation products: Malonaldehyde and 4-hydroxynonenal. Methods Enzymol. 1990, 186, 407-421. [PubMed]

46. Yagi, K. Simple assay for the level of total lipid peroxides in serum or plasma. Methods Mol. Biol. 1998, 108, 101-106. [PubMed]

47. Gosslau, A.; Ruoff, P.; Mohsenzadeh, S.; Hobohm, U.; Rensing, L. Heat shock and oxidative stress-induced exposure of hydrophobic protein domains as common signal in the induction of hsp68. J. Biol. Chem. 2001, 276, 1814-1821. [CrossRef] [PubMed]

48. Mahin, A.A.; Sugimoto, S.; Higashi, C.; Matsumoto, S.; Sonomoto, K. Improvement of multiple-stress tolerance and lactic acid production in Lactococcus lactis NZ9000 under conditions of thermal stress by heterologous expression of Escherichia coli dnaK. Appl. Environ. Microbiol. 2010, 76, 4277-4285. [CrossRef] [PubMed]

49. Mempin, R.; Tran, H.; Chen, C.; Gong, H.; Ho, K.K.; Lu, S. Release of extracellular ATP by bacteria during growth. BMC Microbiol. 2013, 13. [CrossRef] [PubMed]

50. Katsui, N.; Tsuchido, T.; Hiramatsu, R.; Fujikawa, S.; Takano, M.; Shibasaki, I. Heat-induced blebbing and vesiculation of the outer membrane of Escherichia coli. J. Bacteriol. 1982, 151, 1523-1531. [PubMed]

51. Tsuchido, T.; Katsui, N.; Takeuchi, A.; Takano, M.; Shibasaki, I. Destruction of the outer membrane permeability barrier of Escherichia coli by heat treatment. Appl. Environ. Microbiol. 1985, 50, 298-303. [PubMed]

52. Carmel-Harel, O.; Storz, G. Roles of the glutathione- and thioredoxin-dependent reduction systems in the Escherichia coli and saccharomyces cerevisiae responses to oxidative stress. Annu. Rev. Microbiol. 2000, 54, 439-461. [CrossRef] [PubMed]

53. Ackerley, D.F.; Barak, Y.; Lynch, S.V.; Curtin, J.; Matin, A. Effect of chromate stress on Escherichia coli K-12. J. Bacteriol. 2006, 188, 3371-3381. [CrossRef] [PubMed]

54. Smirnova, G.V.; Zakirova, O.N.; Oktiabr'skiř, O.N. Role of the antioxidant system in response of Escherichia coli bacteria to cold stress. Mikrobiologiia 2001, 70, 55-60. [PubMed]

55. Peters, L.P.; Carvalho, G.; Martins, P.F.; Dourado, M.N.; Vilhena, M.B.; Pileggi, M.; Azevedo, R.A. Differential responses of the antioxidant system of ametryn and clomazone tolerant bacteria. PLoS ONE 2014, 9, e112271. 
56. Privalle, C.T.; Fridovich, I. Induction of superoxide dismutase in Escherichia coli by heat shock. Proc. Natl. Acad. Sci. USA 1987, 84, 2723-2726. [CrossRef] [PubMed]

57. Benov, L.; Fridovich, I. A superoxide dismutase mimic protects sodA sodB Escherichia coli against aerobic heating and stationary-phase death. Arch. Biochem. Biophys. 1995, 322, 291-294. [CrossRef] [PubMed]

58. Abrashev, R.; Dolashka, P.; Christova, R.; Stefanova, L.; Angelova, M. Role of antioxidant enzymes in survival of conidiospores of Aspergillus niger 26 under conditions of temperature stress. J. Appl. Microbiol. 2005, 99, 902-909. [CrossRef] [PubMed]

59. Gurunathan, S.; Kalishwaralal, K.; Vaidyanathan, R.; Venkataraman, D.; Pandian, S.R.; Muniyandi, J.; Hariharan, N.; Eom, S.H. Biosynthesis, purification and characterization of silver nanoparticles using Escherichia coli. Colloids Surf. B Biointerfaces. 2009, 74, 328-335. [CrossRef] [PubMed]

60. Gurunathan, S.; Jeong, J.K.; Han, J.W.; Zhang, X.F.; Park, J.H.; Kim, J.H. Multidimensional effects of biologically synthesized silver nanoparticles in Helicobacter pylori, Helicobacter felis, and human lung (L132) and lung carcinoma A549 cells. Nanoscale Res. Lett. 2015, 10. [CrossRef] [PubMed]

61. Gurunathan, S.; Park, J.H.; Han, J.W.; Kim, J.H. Comparative assessment of the apoptotic potential of silver nanoparticles synthesized by Bacillus tequilensis and Calocybe indica in MDA-MB-231 human breast cancer cells: Targeting p53 for anticancer therapy. Int. J Nanomed. 2015, 10, 4203-4222. [CrossRef] [PubMed]

62. Dutta, R.K.; Nenavathu, B.P.; Gangishetty, M.K.; Reddy, A.V. Studies on antibacterial activity of ZnO nanoparticles by ROS induced lipid peroxidation. Colloids Surf. B Biointerfaces 2012, 94, 143-150. [CrossRef] [PubMed]

63. Gurunathan, S. Rapid biological synthesis of silver nanoparticles and their enhanced antibacterial effects against Escherichia fergusonii and Streptococcus mutans. Arabian J. Chem. 2014, 20. [CrossRef]

64. Sheikpranbabu, S.; Haribalaganesh, R.; Gurunathan, S. Pigment epithelium-derived factor inhibits advanced glycation end-products-induced cytotoxicity in retinal pericytes. Diabetes Metab. 2011, 37, 505-511. [CrossRef] [PubMed]

65. Mukherjee, N.; Saini, P.; Mukherjee, S.; Roy, P.; Sinha-Babu, S.P. In vitro antifilarial activity of Azadirachta indica aqueous extract through reactive oxygen species enhancement. Asian Pac. J. Med. 2014, 7, 841-848. [CrossRef]

66. Dănulescu, R.M.; Stanciu, C.; Trifan, A. Assessing the risk of decompensation by ascites and spontaneous bacterial peritonitis in cirrhosis. Rev. Med. Chir. Soc. Med. Nat. Iasi. 2014, 118, 320-326. [PubMed]

Sample Availability: Not available.

(C) 2016 by the authors; licensee MDPI, Basel, Switzerland. This article is an open access article distributed under the terms and conditions of the Creative Commons Attribution (CC-BY) license (http:/ / creativecommons.org/licenses/by/4.0/). 